\title{
A review on Cyperus rotundus A potential medicinal plant
}

\author{
Prof Dr Ali Esmail Al-Snafi \\ Department of Pharmacology, College of Medicine, Thi qar University, Iraq
}

\begin{abstract}
Many previous studies showed Cyperus rotundus contained flavonoids, tannins, glycosides, furochromones, monoterpenes, sesquiterpenes, sitosterol, alkaloids saponins, terpenoids, essential oils, starch, carbohydrates, protein, separated amino acids and many other secondary metabolites. The previous works also showed that the plant exerted antiparasitic, insecticidal, repellent, antibacterial, antioxidant, anticancer, central nervous, neuroprotective, antiinflammatory, antipyretic, analgesic, hypolipidemic, weight control, antiplatelet, gastrointestinal, hepatoprotective, antidiabetic, anti-dysmenorrhea, dermatological and many other effects. This review was designed to highlight the chemical constituents and pharmacological effects of Cyperus rotundus.
\end{abstract}

Keywords:- pharmacology, pharmacognosy, medicinal plants, constituents, Cyperus rotundus

\section{INTRODUCTION}

Herbal medicine is the oldest form of medicine known to mankind. It was the mainstay of many early civilizations and still the most widely practiced form of medicine in the world today[1]. WHO has estimated that perhaps $80 \%$ of the inhabitants of the world rely chiefly on traditional medicines for their primary health care needs. In the developed countries, in the USA, for example, $25 \%$ of all prescriptions dispensed from community pharmacies from 1959 to 1980 contained plant extracts or active principles prepared from higher plants[2]. Plants generally produce many secondary metabolites which were constituted an important source of many pharmaceutical drugs[3]. Many previous reviews revealed the wide range of the pharmacological and therapeutic effects of medicinal plants[4-45]. Phytochemical surveys of Cyperus rotundus revealed that it contained flavonoids, tannins, glycosides, furochromones, monoterpenes, sesquiterpenes, sitosterol, alkaloids saponins, terpenoids, essential oils, starch, carbohydrates, protein, separated amino acids and many other secondary metabolites. It exerted antiparasitic, insecticidal, repellent, antibacterial, antioxidant, anticancer, central nervous, neuroprotective, antiinflammatory, antipyretic, analgesic, hypolipidemic, weight control, antiplatelet, gastrointestinal, hepatoprotective, antidiabetic, anti-dysmenorrhea, dermatological and many other effects. This review was designed to highlight the chemical constituents and pharmacological effects of Cyperus rotundus.

\section{SYNONYMS}

Chlorocyperus rotundus (L.)Palla, Cyperus olivaris Targioni Tozzetti, Cyperus purpurovariegatus Boeckeler, Cyperus stoloniferumpallidus Boeckeler, Cyperus tetrastachyos Desf., Cyperus tuberosus Roxb, Pycreus rotundus (L.) Hayek[46].

Taxonomic classification

Kingdom: Plantae; Subkingdom: Tracheobionta; Superdivision: Spermatophyta;

Division: Magnoliophyta; Class: Liliopsida; Subclass: Commelinidae; Order: Cyperales; Family: Cyperaceae; Genus: Cyperus L; Species: Cyperus rotundus [47].

\section{COMMON NAMES}

Arabic: Sa'ed; Chinese: Suo cao, Xiang fu zi; English: Coco-grass, Ground-almond, Java-grass, Nut sedge, Nut-grass, Purple nut, Sedge, Purple nut-grass, Red nut sedge; French: Souchet rond; German: Knolliges Zypergras; India: Motha, Mutha; Italian: Zigolo infestante; Japanese: Hamasuge; Korean: Hyangbuja; Portuguese: Alho-bravo, Capim-alho, Capim-dandá, Tiririca, Tiririca-vermelha; Spanish: Castañuela, Cipero, Coquito, Juncia real; Swedish: Nötag [48].

\section{DISTRIBUTION}

It was distributed in Africa (Algeria, Egypt, Libya, Morocco, Tunisia, Western Sahara, Chad, Djibouti, Eritrea, Ethiopia, Somalia, Sudan, Kenya, Tanzania, Uganda, Burundi, Equatorial Guinea, Gabon, Rwanda, Zaire, Benin, Burkina Faso, Cote D'Ivoire, Ghana, Guinea, Mali, Mauritania, Niger, Nigeria, Senegal, Sierra Leone, Togo, Angola, Malawi, Mozambique, Zambia, Zimbabwe, Botswana, Namibia, South Africa, Swaziland); Western Indian Ocean (Comoros, Madagascar, Mauritius, Reunion, Seychelles); Western Asia: (Afghanistan, Iran, Iraq, Saudi Arabia, Yemen, Palestine, Lebanon, Syria, Turkey); Caucasus: (Armenia, Azerbaijan, Russian Federation); Middle Asia: (Kazakhstan, Kyrgyzstan, Turkmenistan, Uzbekistan); Eastern 
Asia: China, Japan, Korea, Taiwan, India, Nepal; Pakistan, Sri Lanka, Myanmar; Thailand, Vietnam, Indonesia, Malaysia, Philippines; Europe: (Austria, Switzerland, Albania, Bulgaria, Croatia, Greece, Romania, Serbia, Slovenia, France, Portugal, Spain); Pacific: (Marshall Islands, Micronesia, Northern Mariana Islands); North America: (USA, Mexico); and Southern America (Brazil, Bolivia, Colombia, Ecuador, Peru, Argentina)[48].

\section{DESCRIPTION}

The nut-grass (Cyperus rotundus) is a slender, erect, perennial sedge which spreads by means of a fibrous root system. It is slender, underground, known as rhizomes, are initially white, fleshy and covered with scaly, modified leaves, but become brown and woody with age. On reaching the surface, a rhizomemay swell into a small, rounded structure called a (basal bulb), from which shoots, roots and further rhizomes arise. The rhizomes of the nut-grass also form tubers, which store starch as a food reserve and can give rise new rhizomes or new plants. The tubers measure around 1 to $3.5 \mathrm{~cm}$ in length and are white and succulent when young, later turning brown and hard. The shape of the tubers gives the nut-grass its scientific name, (rotundus), meaning (round). The stems of the nut-grass are smooth and erect, usually reaching around 30 to $40 \mathrm{~cm}$ in height, and are triangular in cross-section. The leaves originate from the base of the plant and are arranged on the stem in groups of three. They are smooth, shiny and dark green, with a grooved upper surface and a sharp tip, and are long and narrow, 20 to $30 \mathrm{~cm}$ in length and 0.2 to $1 \mathrm{~cm}$ in width. The flowers of this species are borne in clusters (inflorescences) at the ends of the stems. The inflorescence consists of around three to nine stalks of varying lengths, at the ends of which are reddish-brown to purple (spikelets). The colour of the spikelets gives the nut-grass its alternative name of (purple nutsedge). Each spikelet $3.5 \mathrm{~cm}$ in length and consists of 10 to 40 flowers, which lack petals, but instead sit within dry, membranous, oval-shaped bracts, known as (glumes). The nut-grass produces a dry, single-seeded fruit, which is up to two millimetres long, and brown to black with a network of grey lines [49-52].

\section{VI- TRADITIONAL USES}

Cyperus rotundus was used for gastrointestinal spasms, stomach disorders, nausea, vomiting, intestinal parasites, food poisoning, indigestion and irritation of bowel. It was also used for treating fevers, to treat wounds, bruises and carbuncles, malaria, cough, bronchitis, renal and vesical calculi, urinary tenesmus, amenorrhoea, dysmenorrhoea, deficient lactation, loss of memory, insect bites, dysuria, bronchitis, infertility, cervical cancer and menstrual disorders, while, the aromatic oils are made of perfumes and splash [53-57]. According to the Ayurveda, Cyperus rotundus rhizomes were considered astringent, diaphoretic, diuretic, analgesic, antispasmodic, aromatic, carminative, antitussive, emmenagogue, litholytic, sedative, stimulant, stomachic, vermifuge, tonic and antibacterial[58].

\section{Physicochemical properties}

Physicochemical parameters of Cyperus rotundus rhizome (w/w): moisture 9\%, total ash 8.06$12.87 \%$, acid insoluble ash 2.23-4.56 \%, water soluble ash 5.1-6.4\%, sulphated ash 9.56-10.22\%. Extractive values of Cyperus rotundus rhizome: water soluble extract 9.01-15.15\% alcohol soluble extract 7.63-21.27\%. Successive extraction (petroleum ether $\left(60-80^{\circ} \mathrm{C}\right) 1.27-1.53 \%$, chloroform $2.52 \%$, n-hexane $1.79 \%$, acetone 1.82, alcohol (90\%) $1.78 \%$, aqueous $1.47 \%$ ). Loss on drying, 3.57\% and crude fiber content 39.98\%[59-61].

\section{VII- CHEMICAL CONSTITUENTS}

Phytochemical surveys revealed that the plant contained flavonoids, tannins, glycosides, furochromones, monoterpenes, sesquiterpenes, sitosterol, alkaloids saponins, terpenoids, essential oils, starch, carbohydrates, protein and amino acids [59-63].

Cyperus rotundus contained many secondary metabolites such as sesquiterpenes (with diverse skeletons such as patchoulane, rotundane, eudesmane, guaiane, cadinane and caryophyllene types), quinones, flavonoids (visnagin, khellin, ammiol, isorhamnetin, and tricin), saponins, alkaloids, phenolic acids (salicylic acid, protocatechuic acid, caffeic acid and $p$ coumaric acid), coumarins and steroids (steroidal glycoside, sitosteryl(6'-hentriacontanoyl)-ß3-dgalactopyranoside) [64].

The percentage of essential oils in Cyperus rotundus tubers was ( $0.19 \%)$, with a specific gravity (0.9689) and refractive index (1.54051). Fifty two compounds were isolated from Cyperus rotundus from Egypt. (+) oxo- $\alpha-$ ylangene $(9.35 \%),(+) \alpha$-cyperone $(9.07 \%)$ trans-pinocarveol $(7.92 \%)$ and cyperene $(7.83 \%)$ were the major constituents in the oil of Cyperus rotundus. However, the essential oils isolated from the tubers of Cyperus rotuntdus and their percentage were: $\alpha$-pinene 2.87 , cyclopentene-3-ethylidene-1-methyl 0.24 , sabinene 0.43 , $\beta$-pinene 2.13, p-cymene, 0.18, 1-limonene 0.28, 8-cineole 0.36, trans-pinocarveol 7.92, terpinen-4ol 0.59 , citronellal $0.76,4,4$-dimethyl-tricyclo-(3,2,1) octan-6-on 1.56, p-cymen-8-ol 1.96, 1- $\alpha$-terpineol 1.45 , cis-dihydrocarvone 0.38 , myrtenol 1.86 , verbenone $1.55,1-\beta-4,4$-trimethyl-bicyclo $(3,2)$ hept- 6 -en-2ol - 1.05, trans-carveol 0.48 , carvone 1.95 , carvenone 0.32 , $\alpha$-cubebene 0.40 , dihydro-carvylacetate 
0.93, $\alpha$-copaene 3.02, isolongifoline 1.66, cyperene 7.83, trans-caryophyllene 3.08, dihydroaromadendrene 1.47, aromadendrene-epoxide 2.51, naphthalene, 1,6-dimethyl-4-(1-methyl ethyl) $1.09, \alpha$ silenene 0.55, cis-calamenene 0.42, trans-calamenene 0.57, elema-1,3,11 (13)-trien-12-ol 0.64, caryophyllene-oxide $\quad 2.86$, cis-12-caryophyll-5-en-2-one $\quad 2.4$, caryophylla-2(12), 6(13) dien-5-one 1.95, cyclohexane, 1,1,2-trimethyl,3,5 bis- 1-methyl ethyl) 0.97, cyclo-hexenone, 2,3,3-trimethyl (3-methylbutadienyl) 1.06, isopropyl, 4a $\beta, 8$ a $\beta$-dimethyl 3.69, longiverbenone 1.09 , 10-epi- $\alpha$-cyperone $1.00,(+)$ oxo- $\alpha$-ylangene 9.35, (+) $\alpha$-cyperone 9.07, caryophyllenol 2.11, vulgarol A 1.13 , vellerdiol 0.77 , aristolone 3.54, vulgarol B 0.98, ledenoxide 1.34, dimethyl-7-isopropenyl-bicyclo- Dec-1-en-3-one 2.95, longifolinaldehyde 0.27 and longipynocarvone 2.95[65-66]. However, essential oils represented $0.2 \%$ (w/w) in the Cyperus rotuntdus tubers, growing wild in Isfahan province (Iran). Sixty natural compounds were identified from its essential oil. Sesquiterpene compounds represented the largest amounts in the oil. Among the oil constituents, cyperene $(16.9 \%)$, caryophyllene oxide $(8.9 \%), \alpha$-longipinane $(8.4 \%)$ and $\beta$-selinene $(6.6 \%)$ represented the major components [62].

Total flavonoids contents in methanol extracts of Cyperus rotundus (8.15-18.25 mg CE/g of dry matter) were higher as compared to ethanol extracts (6.44-13.77 mg CE/g of dry matter). Total phenolic contents in methanol extracts of Cyperus rotundus (27.40-37.85 mg GAE/g of dry matter) were also higher as compared to ethanol extracts (25.21-30.23 mg GAE/g of dry matter)[67].

\section{VIII- PHARMACOLOGICAL EFFECTS ANTIMICROBIAL EFFECT}

The antimicrobial activity of oils of Cyperus rotuntdus was studied by disc agar diffusion method. The diameters of zones of inhibition were measured comparing with negative control, as well as ofloxacine, rifampicine and amphotricine B $(5 \mu \mathrm{g} / \mathrm{disc})$ as positive control for each micro-organism. Cyperus rotundus essential oil was significantly active against Gram-positive microorganisms (Staphylococcus aureus and Streptococcus species), moderately active against Sarcina lutea, Bacillus subtilis and the acid fast Mycobacterium phlei and fungi (Candida species). The oil is completely inactive against Gram- negative microorganisms[65].

Cyperus rotundus rhizomes petroleum ether, chloroform, ethanol and water extracts were evaluated against six important pathogenic microbes (Staphylococcus epidermidis, Bacillus cereus, Pseudomonas aeruginosa, Escherichia coli, Aspergillus niger and Candida). The antibacterial and antifungal activities were performed by both agar well diffusion and serial dilution methods. The ethanolic extract exhibited highest activity against the tested bacteria. However all extracts were ineffective against fungal strains. The inhibitory effect is very similar and comparable with that of standard drug[68].

The growth and acid production of Streptococcus mutans were reduced by the tuber extract of Cyperus rotundus. S. mutans is known as the causative bacteria in the formation of dental plaque and dental caries. Moreover, the same tuber extract inhibited the adherence of $S$. mutans to saliva coated hydroxyapatite beads. Glucosyl transferase enzyme, which synthesized water-insoluble glucan from sucrose, was also inhibited by the tuber extract. Accordingly Cyperus rotundus inhibited cariogenic properties of S. mutans[69].

The oil of Cyperus rotundus was tested against various bacterial and fungal strains (Bacillus subtilis, Escherichia coli, Pseudomonas aeruginosa and Staphylococcus aureus, Candida parapsilosis, Aspergillus flavus, Aspergillus fumigatus and Fusarium oxysporum) in different concentrations. At $100 \%$ concentration the oil showed good activity against Escherichia coli, Staphylococcus aureus, Bacillus subtilis and Pseudomonas aeruginosa and less activity against Micrococcus luteus and Klebsiella sp. At low concentration the oil was also effective against $S$. aureus. Oil also showed good antifungal activity against Candida parapsilosis and Aspergillus fumigatus. It also inhibited spore formation of Fusarium oxysporum and Aspergillus flavus[66].

The antibacterial properties of Cyperus rotundus root extracts (petroleum ether, acetone, methanol and water) was investigated against three Gram-positive and two Gram-negative bacteria causing respiratory tract infections. Results showed that methanol extract was the most active as comparison to other extract. The maximum inhibition was noted against $H$. influenzae $(18.4 \pm 0.07 \mathrm{~mm})$ followed by $S$. pyogenes $(17.3 \pm 0.13 \mathrm{~mm}), P$. aeruginosa $(16.2 \pm 0.07 \mathrm{~mm})$ and $S$. pneumoniae $(15.5 \pm 0.15 \mathrm{~mm})$ and the minimum activity was recorded against $S$. aureus $(15.3 \pm 0.05 \mathrm{~mm})$ respectively[70]. Methanolic extract of the fresh aerial part of the Cyperus rotundus was fractionated by column chromatographymethod using petroleum ether, chloroform, ethyl acetate and methanol. The in vitro antibacterial activity was carried out against (Bacillus subtilis, Staphylococcus aureus, Escherichia coli and Pseudomonas aeruginosa ) for all fractions. The ethyl acetate fraction showed potent antibacterial activity compared to control and standard commercial antibiotic tetracycline [71].The Antibacterial activity of Cyperus oil was studied against (Staphylococcus aureus, Klebsiella pneumoniae, Proteus vulgaris, Streptococcus pyogenes, Eschirichia coli and Pseudomonas aeruginosa). The MIC and MBC for each microbe were estimated. The oil of Cyperus rotundus exerted 
remarkable activity against Gram-positive bacteria, less antibacterial activity was recorded against Gramnegative bacteria and no activity against Pseudomonas aeruginosa and Proteus vulgaris[72]. Antimicrobial activity of Cyperus routunds ethanolic extract was carried out on human pathogenic bacteria such as Morexilla catarhalis, Escherichia coli, Klebsiella pneumoniae, Pseudomonas aeruginosa, Staphylococcus aureus, Acinetobacter and fungi Candida albicans and Aspergillus niger. Excellent, moderate low and no activity were found on these organism. Ethanolic extract caused $133.3 \%$ inhibition of $K$. pneumoniae as compared to standard drug amoxicillin $20 \mu \mathrm{g} / \mathrm{ml}$. In case of A. niger and S. aureus 90 and $70 \%$ inhibition was observed respectively, while the ethanolic extract showed low inhibition (46.66, 37.5 and $33.3 \%$ in E coli, P. aeruginosa and $M$. catarhalis respectively). No zone of inhibition was observed in Acinetobacter and C. albican[73]. Cyperus rotundus exerted virucidal effect against HSV[74]. Anti-HBV active constituents was isolated from the rhizomes of Cyperus rotundus. Five new patchoulane-type sesquiterpenoids, namely cyperene-3, 8-dione, 14hydroxy cyperotundone, 14-acetoxy cyperotundone, 3ß-hydroxycyperenoic acid and sugetriol-3, 9-diacetate, along with 32 known sesquiterpenoids were isolated from the active fractions of Cyperus rotundus. Nine eudesmane-type sesquiterpenoids significantly inhibited the HBV DNA replication with $\mathrm{IC}_{50}$ values of $42.7 \pm 5.9$, $22.5 \pm 1.9,13.2 \pm 1.2,10.1 \pm 0.7,14.1 \pm 1.1,15.3 \pm 2.7,13.8 \pm 0.9,19.7 \pm 2.1$ and $11.9 \pm 0.6 \mu \mathrm{M}$, of which, 4 compounds possessed high SI values of 250.4, 125.5, >259.6 and 127.5. Two patchoulane-type sesquiterpenoids effectively suppressed the secretion of $\mathrm{HBsAg}$ in a dose-dependent manner with $\mathrm{IC}_{50}$ values of $46.6 \pm 14.3$ $(\mathrm{SI}=31.0)$ and $77.2 \pm 13.0(\mathrm{SI}=1.7) \mu \mathrm{M}$. Other 6 compounds possessed moderate activities against $\mathrm{HBeAg}$ secretion with $\mathrm{IC}_{50}$ values of $162.5 \pm 18.9$ ( $\left.\mathrm{SI}=13.3\right)$, 399.2 $\pm 90.0 \quad(\mathrm{SI}=10.6), 274.7 \pm 70.8$ (SI=5.2), 313.9 \pm 87.5 $(\mathrm{SI}=7.2), 334.0 \pm 70.4(\mathrm{SI}=9.9)$ and $285.3 \pm 20.9(\mathrm{SI}=15.5) \mu \mathrm{M}[75]$.

\section{ANTIPARASITIC, INSECTICIDAL AND REPELLENT}

Hexane extract of tuber of plant Cyperus rotundus was tested for repellent activity against mosquito vector Anopheles culicifacies, Anopheles stephensi and Culex quinquefasciatus. Results showed that the tuber extracts were effective for repellency of the entire mosquito vector even at a low dose [76].Cyperus rotundus was more effective insecticidal than carbamate and has almost the same efficacy as that of organophosphate. Result showed that all the test ants died after 10s, while organophosphate ranked second with 9 ants dead after 10s, and the carbamate ranked third with seven ants dead after 12s[77].The ovicidal and larvicidal efficacy ofessential oils of the tubers of Cyperus rotundus was studied on eggs and fourth instar larvae of Aedes albopictus. The eggs and larvae were exposed to serial concentration of the oils ranging from 5-150 ppm and observed for $24 \mathrm{~h}$. Oils showed remarkable ovicidal and larvicidal activities indicated by $\mathrm{EC}_{50}$ values of $<5 \mathrm{ppm}$ and $\mathrm{LC}_{50}$ and $\mathrm{LC}_{90}$ values of $<20 \mathrm{ppm}$ [78].Activity-guided investigation of Cyperus rotundus tubers led to the isolation of patchoulenone, caryophyllene alpha-oxide, 10,12-peroxycalamenene and 4,7-dimethyl-1-tetralone. The antimalarial activities of these compounds were in the range of $\mathrm{EC}_{50} 10^{-4}$ to $10^{-6} \mathrm{M}$, with the novel endoperoxide sesquiterpene, 10,12-peroxycalamenene, exhibiting the strongest effect at $\mathrm{EC}_{50} 2.33 \times 10^{-6} \mathrm{M}[79]$.

\section{CENTRAL NERVOUS EFFECT}

The ethanolic extract of Cyperus rotundus showed potent tranquilizing activity in many tests. It reduced the spontaneous motor activity, potentiated the pentobarbital narcosis and deranged the motor coordination and abolished the conditioned avoidance response in animals[80].

Open field, head dip, rearing traction and forced swimming test were used to study the neuropharmacological of 300 and $500 \mathrm{mg} / \mathrm{kg}$ of Cyperus rotundus extract. The crude extract showed mild decreased in all tests and exhibited slight muscle relaxant effect[81].

The behavioral studies on mice indicated CNS depressant activity of the ethanol extract of Cyperus rotundus. The ethanol extract of Cyperus rotundus significantly potentiated the sleeping time of mice induced by standard hypnotics (pentobarbitone sodium, diazepam, and meprobamate) in a dose dependent manner[82].

Four sesquiterpenes (beta-selinene, isocurcumenol, nootkatone and aristolone) and one triterpene (oleanolic acid) were isolated from the ethylacetate fraction of the rhizomes of Cyperus rotundus and tested for their ability to modulate gamma-aminobutyric acid $\left(\mathrm{GABA}_{\mathrm{A}}\right)$-benzodiazepine receptor function by radioligand binding assays using rat cerebrocortical membranes. Among these compounds, only isocurcumenol was found to inhibit $\left[{ }^{3} \mathrm{H}\right]$ Ro15-1788 binding and enhance $\left[{ }^{3} \mathrm{H}\right]$ flunitrazepam binding in the presence of GABA. The results suggested that isocurcumenol may serve as a benzodiazepine receptor agonist and allosterically modulated GABAergic neurotransmission via enhancement of endogenous receptor ligand binding[83].

The anticonvulsant activity of Cyperus rotundus essential oils was evaluated using MES produced convulsion in rats. The essential oil of Cyperus rotundus $500 \mathrm{mg} / \mathrm{kg}$, significantly decreased the duration 
$(\mathrm{p}<0.01)$, of clonus $(12.00 \pm 0.7303 \mathrm{~s})$ and stupor $(74.20 \pm 0.6325 \mathrm{~s})$ phase of MES induced convulsion as compared to control[84].

The anticonvulsant effect of Cyperus rotundus extract was also experimentally examined in mice. Mice received Cyperus rotundus rhizome extract at three doses (100, 200 and $400 \mathrm{mg} / \mathrm{kg}$; ip). All groups except for control group, were kindled by 11 injections of PTZ ( $35 \mathrm{mg} / \mathrm{kg}$; ip) with an interval of $48 \mathrm{~h}$. In the $12^{\text {th }}$ injection, all groups except for control group, were tested for PTZ challenge dose $(75 \mathrm{mg} / \mathrm{kg})$. The exhibited phases of seizure (0-6) were observed and noted for 30 min after PTZ injection. All brains of mice were removed and then malondialdehyde (MDA), superoxide dismutase (SOD) and nitric oxide (NO) levels of brain tissues were determined. Data analysis showed that the hydroalcoholic extract of Cyperus rotundus reduced intensity and duration of seizure and increased the level of SOD and NO and decrease MDA level in mice brain[85].

The anticonvulsant effect of Cyperus rotundus roots and rhizomes was studied in seizures induced by pentylenetetrazol (PTZ) and picrotoxin (PTX) in mice. Pretreatment with hydroalcoholic extract of Cyperus rotundus roots and rhizomes $(50-200 \mathrm{mg} / \mathrm{kg})$ induced a dose-dependent decrease in the incidence of both clonic and generalized tonic-clonic seizures $(\mathrm{p} \leq 0.05)$ following PTZ and PTX administration. Coadministration of a sub-effective dose of CR $(50 \mathrm{mg} / \mathrm{kg}$, po) with a sub-protective dose of diazepam $(0.5 \mathrm{mg} / \mathrm{kg}$, ip) increased the latency to seizure. The combination significantly enhanced percent protection against PTZ and PTX induced convulsions. The authors suggested that the anticonvulsant effect of Cyperus rotundus roots and rhizomes against PTZ and PTX induced convulsions may be mediated, at least partly, through $\mathrm{GABA}_{\mathrm{A}^{-}}$ benzodiazepine receptor complex[86].

Pretreatment with the ethanol extract of Cyperus rotundus caused significant protection against strychnine and leptazol-induced convulsions [82]. The effect of the extract and essential oil of Cyperus rotundus on memory dysfunction was studied in mice. Cognition was evaluated using the object recognition task that was composed of a square wooden open field box with different shape objects. The test was consisted of three sections: $15 \mathrm{~min}$ exploration, first trial for $12 \mathrm{~min}$ and second one for $5 \mathrm{~min}$. In the second trial the difference in exploration between a previously seen object and novel one, was considered as an index of memory performance (recognition index). Memory deficit was induced by scopolamine $(0.5 \mathrm{mg} / \mathrm{kg}$ ) before injection of plant extracts and essential oil. Neither the hydroalcholic extracts $(100,200,400 \mathrm{mg} / \mathrm{kg}$ ) nor the polyphenolic extract $(50,100,200 \mathrm{mg} / \mathrm{kg})$ and essential oil $(10,20,40 \mathrm{mg} / \mathrm{kg})$ of Cyperus rotundus produced significant improvement of memory dysfunction[87].

\section{NEUROPROTECTIVE EFFECT}

The neuroprotective effects of a water extract of Cyperus rotundus rhizoma against 6hydroxydopamine (6-OHDA)-induced neuronal damage were evaluated in an experimental model of Parkinsons disease. In PC12 cells, water extract of Cyperus rotundus rhizoma showed a significant protective effect on cell viability at 50 and $100 \mathrm{microg} / \mathrm{ml}$. Water extract of Cyperus rotundus rhizoma inhibited generation of reactive oxygen species and nitric oxide, reduction of mitochondrial membrane potential, and caspase- 3 activity, which were induced by 6-OHDA. Water extract of Cyperus rotundus rhizoma also showed a significant protective effect against damage to dopaminergic neurons in primary mesencephalic culture[88].

The possible neuroprotective effects of the ethanol extract of Cyperus rotundus on a model of global transient ischemia in rat was investigated by evaluating the pathophysiology of the hippocampal tissue and spatial memory. The group treated with the ethanol extract of Cyperus rotundus $(100 \mathrm{mg} / \mathrm{kg} / \mathrm{day})$ was gavaged from 4 days before, to 3 days after ischemia. Morris water maze test was performed 1 week after ischemia for 4 days. Brain tissue was prepared for Nissl staining. Data showed no statistical difference between the treatment and ischemia groups in water maze task. So, treatment of ischemia with the ethanol extract of Cyperus rotundus cannot improve spatial learning and memory. On the contrary the ethanol extract of Cyperus rotundus ameliorated the CA1 pyramidal cell loss due to transient global ischemia/reperfusion injury[89].

The neuroprotective effect of total oligomeric flavonoids (TOFs), prepared from Cyperus rotundus, was studied in rat model of cerebral ischemia and reperfusion. Male Sprague Dawley rats were subjected to middle cerebral artery occlusion (MCAO) for $2 \mathrm{~h}$ and reperfusion for $70 \mathrm{~h}$. Experimental animals were divided into four groups: Group I - sham operated; Group II - vehicle treated ischemic-reperfusion (IR), and Group III and IV - TOFs treated (100 and 200mg/kg body weight, po, respectively). Vehicle or TOFs were pretreated for four days before the induction of ischemia and continued for next three days after the ischemia i.e. treatment was scheduled totally for a period of 7 days. MCAO surgery was performed on day $4,1 \mathrm{~h}$ after TOFs administration. Neuroprotective effect of TOFs was substantiated in terms of neurological deficits, excitotoxicity (glutamate, glutamine synthetase and $\mathrm{Na}^{+}-\mathrm{K}^{+}$-ATPase levels), oxidative stress (malondialdehyde, super oxide dismutase, and glutathione) and neurobehavioral functions in the experimental animals. TOFs decreased glutamate, glutamine synthetase (GS) and increased $\mathrm{Na}^{+}-\mathrm{K}^{+}$-ATPase activity in a dose dependent 
manner when compared to the IR rats. Treatment with TOFs significantly reduced the neurological deficits and reversed the anxiogenic behavior in rats. Furthermore, it also significantly decreased MDA and increased superoxide dismutase (SOD) and glutathione content in brains of experimental rats. Histopathological examination using cresyl violet staining revealed the attenuation of neuronal loss by TOFs in stroke rats[90].

The protective effect of 200 and $400 \mathrm{mg} / \mathrm{kg}$ of ethanol extract of Cyperus rotundus against sodium nitriteinduced hypoxia injury in rats was evaluated by assessing the cognitive functions, motor, and behavioral effects of ethanol extract of Cyperus rotundus treatment along with the histological changes in the brain. Ethanol extract of Cyperus rotundus at doses of 200 and $400 \mathrm{mg} / \mathrm{kg}$ was able to protect against the cognitive impairments, and the locomotor activity and muscular coordination defects, which were affected by sodium nitrite-induced hypoxia injury in rats[91].

The protective effects of Cyperus rotundus rhizome extract were evaluated through its oxidonitrosative and anti apoptotic mechanism to attenuate peroxynitrite (ONOO${ }^{-}$) induced neurotoxicity, using humanneuroblastoma SH-SY5Y cells. The results elucidate that pre-treatment of neurons with Cyperus rotundus rhizome extract ameliorates the mitochondrial and plasma membrane damage induced by $500 \mu \mathrm{M}$ SIN-1 to $80 \%$ and $24 \%$ as evidenced by MTT and LDH assays. CRE inhibited NO generation by down-regulating i-NOS expression. SIN-1 induced depletion of antioxidant enzyme status was also replenished by Cyperus rotundus rhizome extract which was confirmed by immunoblot analysis of SOD and CAT. The Cyperus rotundus rhizome extract pre-treatment efficiently potentiated the SIN-1 induced apoptotic biomarkers such as bcl-2 and caspase-3 which orchestrate the proteolytic damage of the cell. The $\mathrm{ONOO}^{-}$induced damage to cellular, nuclear and mitochondrial integrity was also restored by Cyperus rotundus rhizome extract. Furthermore, Cyperus rotundus rhizome extract pre-treatment also regulated the 3-NT formation which revealed the potential of plant extract against tyrosine nitration[92].

\section{ANTIINFLAMMATORY, ANTIPYRETIC AND ANALGESIC EFFECTS}

The alcoholic extract (70\% alcohol) possessed antiinflammatory activity against carrageenan induced oedema and against formaldehyde induced arthritis in albino rats[93].The anti-inflammatory activity of crude extract of Cyperus rotundus was studied in rats at a dose of $(300 \mathrm{mg} / \mathrm{kg}$ and $500 \mathrm{mg} / \mathrm{kg})$. Inflammation was produced by carrageenan in rats and compare with saline and aspirin treated groups. Plant extract exhibited significant anti inflammatory effect[81].The Anti-inflammatory, anti-arthritic and analgesic of Cyperus rotundus essential oils were evaluated using anti-inflammatory (carrageenan induced), antiarthritic (formaldehyde induced) and analgesic (formalin induced writhing) in rats. The results showed dose dependent activity, indicated by reduction in paw edema in anti-inflammatory and antiarthritic activity. When compared with the control, treatment with Cyperus rotundus significantly $(\mathrm{p}<0.01)$ reduced the paw edema from $2^{\text {nd }} \mathrm{hr}$ after carrageenan injection. Pretreatment with Cyperus rotundus at doses of 250 and $500 \mathrm{mg} / \mathrm{kg}$ showed a dose dependent effect. The assessment of anti-arthritic activity on the $10^{\text {th }}$ day showed that, treatment with Cyperus rotundus $(500 \mathrm{mg} / \mathrm{kg})$ significantly reduced $(\mathrm{p}<0.01)$ the swelling in the injected (left) hind paw as compared to Diclofenac sodium treated group. On the $10^{\text {th }}$ day the $\%$ inhibition of paw edema exhibited by Cyperus rotundus $(500 \mathrm{mg} / \mathrm{kg})$ was $75.54 \%$. Analgesic effects was evaluated on both first (0-5 min) and second (15-30 min) phases of formalin induced pain. The phases corresponded to neurogenic and inflammatory pains, respectively. Essential oil inhibited both, neurogenic and inflammatory pain $(\mathrm{p}<0.01)$ at dose of $500 \mathrm{mg} / \mathrm{kg}$, whereas lower doses of essential oil significantly $\mathrm{p}<0.05$ blocked the inflammatory pain[84].

Aqueous, ethyl acetate, methanol and TOF-enriched extracts of Cyperus rotundus $(300,150$, and $50 \mu \mathrm{g} / \mathrm{ml})$ were evaluated for their analgesic and anti-inflammatory activitiesin mice. The tested extracts were able to decrease the mouse ear oedema induced by xylene and reduced the number of abdominal contractions caused by acetic acid, revealing the peripheral analgesic activity of these extracts. No toxicity was recorded in mice treated with doses up to $300 \mathrm{mg} / \mathrm{kg}$ bw[94].

Tail flick method was used for the determination of analgesic activity. The temperature and duration were $51 \pm 1 \mathrm{C}^{\circ}$ and $0,1,2,3$ and 4 hours respectively. Cyperus routunds ethanolic extract 300 and $500 \mathrm{mg} / \mathrm{kg}$ orally showed significant analgesic activity[73]. The ethanol extract of Cyperus rotundus showed significant analgesic properties as evidenced by the significant reduction in the number of writhes and stretches induced in mice by $1.2 \%$ acetic acid solution. It also potentiated analgesia induced by morphine and pethidine in mice[82].The antinociceptive activity of the extract of whole plant of Cyperus rotundus was investigated in thermal-induced (hot plate and tail immersion) and chemical-induced (formalin) nociception models in mice at three different doses $(50,100$ and $200 \mathrm{mg} / \mathrm{kg}$; po). Morphine sulphate $(5 \mathrm{mg} / \mathrm{kg}$, ip.) and diclofenac sodium $(10 \mathrm{mg} / \mathrm{kg}$, ip) were used as reference analgesic agents. In the hot-plate and tail-immersion tests, the extract significantly increased the latency period to the thermal stimuli at all the tested doses (50, $100 \mathrm{and} 200 \mathrm{mg} / \mathrm{kg}$ ) $(\mathrm{p}<0.05)$. The significant increase in latency was clear from the observations at 60 and $90 \mathrm{~min}$. In formalininduced paw licking test oral administration of extract of whole plant of Cyperus rotundus at 100 and $200 \mathrm{mg} / \mathrm{kg}$ 
doses decreased the licking of paw in early phase. All the tested doses (50, 100 and $200 \mathrm{mg} / \mathrm{kg}$ ) significantly decreased the licking of paw in late phase of the test $(\mathrm{p}<0.001)$. The dose $200 \mathrm{mg} / \mathrm{kg}$ was most effective showing maximum percentage of inhibition of licking in both early $(61.60 \%)$ and late phase (87.41\%)[95].The effect of Cyperus rotundus extract and its constituents was studied on the transient receptor potential vanilloid 1 channel (which was a nonselective cation channel that senses various noxious chemical and thermal stimuli, and involves in heat- and UV-induced skin aging). Ethylacetate and hexane fractions of the methanol extract were found to partially inhibit transient receptor potential vanilloid 1 channel activity, and at a concentration of $90 \mu \mathrm{M}$, oleanolic acid, which was one of three constituents isolated from the ethylacetate fraction, inhibited this activity by $61.4 \pm 8.0 \%$. The results highlight the potential therapeutic effects of Cyperus rotundus in the contexts of analgesia and UV-induced photo-aging[96].

The alcoholic extract of Cyperus rotundus showed significant $(\mathrm{p}<0.001)$ antipyretic activity against pyrexia induced in rats by the subcutaneous injection of suspension of dried Brewer's yeast in gum acacia in normal saline[80].

The alcoholic extract of Cyperus rotundus showed highly significant $(\mathrm{p}<0.001)$ antipyretic activity against pyrexia produced in albino rats by the subcutaneous injection of suspension of dried Brewer's yeast. However, a specific fraction obtained from the petroleum ether extract showed significant anti-pyretic effect similar to acetyl salicylic acid. The petroleum ether extract and essential oil of Cyperus rotundus possessed analgesic activity[97-98].

Two models of acute inflammation, carrageenan induced rat paw edema and acetic acid induced peritonitis in mice were used to investigate the anti-inflammatory effect of Cyperus rotundus. In the model of carrageenan induced paw edema Cyperus rotundus showed a trend to reduce the edema, whereas in a model of acetic acid induced peritonitis, Cyperus rotundus induced significant decrease in the protein content of the peritoneal exudates compared with the disease control group $(\mathrm{p}<0.05)$ [99].

Clinical studies with $2 \%$ aqueous extract of Cyperus rotundus showed anti-inflammatory activity in conjunctivitis in human[100].

A double blind trial of crude powder of Cyperus rotundus, Withania somnifera and their combination (1:1) was carried out in 200 patients suffering from rheumatoid arthritis. Each patient received $500 \mathrm{mg}$ capsule three times a day for three months. During this period biweekly general assessment based on global criteria (duration of morning stiffness, grip strength, articular index, consumption of escape analgesic, erythrocyte sedimentation rate, haemoglobin, rheumatoid factor titre, x-ray findings) was carried out. Cyperus rotundus was more effective than Withania somnifera, and when both drugs were combined, the response was better than the response of single drug[101].

A study was undertaken to investigate the effect of metanol extract of rhizomes of Cyperus rotundus on $\mathrm{NO}$ and $\mathrm{O}^{2-}$ productions by murine macrophage cell line, RAW 264.7 cells. The methanolic extract of rhizomes of Cyperus rotundus inhibited NO production in a dose-dependent manner by RAW 264.7 cells stimulated with interferon-gamma plus lipopolysaccharide. The inhibition of NO production by the extract was due to the suppression of iNOS protein, as well as iNOS mRNA expression, determined by western and northern blotting analyses, respectively. In addition, the methanolic extract suppressed the production of $\mathrm{O}^{2-}$ by phorbol ester-stimulated RAW 264.7 cells in dose- and time-dependent manners. Collectively, the results suggest that the methanolic extract of rhizomes of Cyperus rotundus could be developed as anti-inflammatory candidate for the treatment of inflammatory diseases mediated by overproduction of NO and $\mathrm{O}^{2-}[102]$.The $\mathrm{n}$-hexane fraction of the $80 \%$ ethanoic extract from the rhizomes of Cyperus rotundus was found to inhibit both $\mathrm{NO}$ and $\mathrm{PGE}_{2}$ production in RAW 264.7 cells. $\alpha$-Cyperone isolated from the n-hexane fraction significantly inhibited $\mathrm{PGE}_{2}$ production by suppressing the LPS-induced expression of inducible COX-2 at both the mRNA and the protein levels. In contrast, $\alpha$-cyperone had little effect on NO production and iNOS expression. Additionally, $\alpha$-cyperone down regulated the production and mRNA expression of the inflammatory cytokine IL-6. Moreover, treatment with $\alpha$-cyperone suppressed the transcriptional activity of NFkB and the nuclear translocation of the p65 NFkB subunit in LPS-induced RAW 264.7 cells[103].

The role of heme oxygenase $\mathrm{HO}^{-1}$ induction in anti-inflammatory effect of extract rhizomes of Cyperus rotundus was investigated. Induction of $\mathrm{HO}^{-1}$ and inhibition of inducible nitric oxide synthase (iNOS)/NO production by extract of rhizomes of Cyperus rotundus and its 12 constituents ( 3 monoterpenes, 5 sesquiterpenes, and 4 aromatic compounds) were investigated using RAW264.7 cells in vitro. In addition, antiinflammatory action of extract of rhizomes of Cyperus rotundus and its two active ingredients (nookkatone, valencene) were confirmed in sepsis animal model in vivo. The extract of rhizomes of Cyperus rotundus increased $\mathrm{HO}^{-1}$ expression in a concentration-dependent manner, which was correlated with significant inhibition of iNOS/NO production in LPS-activated RAW264.7 cells. Among 12 compounds isolated from the extract of rhizomes of Cyperus rotundus, sesquiterpenes induced stronger $\mathrm{HO}^{-1}$ expression than monoterpenes in macrophage cells. Nootkatone and valencene (sesquiterpenes) significantly inhibited iNOS expression and NO production in LPS-simulated RAW264.7 cells. Inhibition of iNOS expression by nootkatone, valencene, 
and extract rhizomes of Cyperus rotundus were significantly reduced in si $\mathrm{HO}^{-1} \mathrm{RNA}$ transfected cells. Furthermore, all three showed marked inhibition of high mobility group box-1 (HMGB1) in LPS-activated macrophages and increased survival rates in cecal ligation and puncture (CLP)-induced sepsis in mice[104].

\section{ANTICANCER EFFECT}

Brine shrimp bioassay was used to investigate the toxic action of Cyperus routunds ethanolic extract in comparison to etoposide standard. Cyperus routunds ethanolic extract showed non toxic significant effects at 10, $100,1000 \mu \mathrm{g} / \mathrm{ml}$ concentrations[73].Different concentrations of oil of Cyperus rotuntdus were prepared using DMSO $(100,50$ and $25 \mu \mathrm{g} / \mathrm{ml})$ and screened in vitro using Ehrlich ascites carcinoma cells (EAC) $25 \times 10^{6}$ tumor cells per $\mathrm{ml}$ suspended in phosphate buffer saline. $0.1 \mathrm{ml}$ of the prepared oils were added to the suspension and kept at $37^{\circ} \mathrm{C}$ for two hours. Trypan blue dye exclusion test was carried out to calculate the percentage of non viable cells. Oils were also tested for cytotoxic activity against the human tumor cell lines (brain tumor cell line) and Hela (cervix carcinoma cell line) at concentration between 1-10 $\mu \mathrm{g} / \mathrm{ml}$ using SRB assay. Ehrlich ascites carcinoma cells in vitro showed that the oil exerted significant antitumour activity. Cyperus rotuntdus essential oils showed 100\% inhibition of tumour cells at all concentrations tested $(25,50$ and $100 \mu \mathrm{g} / \mathrm{ml}$ ). But when the oils tested against the human tumour cell lines (U 251 and Hela) they showed negative results[65].The mutagenic and antimutagenic effects of aqueous, total oligomers flavonords (TOF), ethyl acetate and methanol extracts from aerial parts of Cyperus rotundus were assayed by Salmonella typhimurium assay system. The different extracts showed no mutagenicity when tested with Salmonella typhimurium strains TA98, TA100, TA1535 and TA1538, either with or without the S9 mix. On the other hand, the results showed that all extracts possessed antimutagenic activity against aflatoxin B1 (AFB1) in TA100 and TA98 assay system, and against sodium azide in TA100 and TA1535 assay system. TOF, ethyl acetate and methanol extracts exhibited the highest inhibition level of the Ames response induced by the indirect mutagen AFB1. Furthermore, ethyl acetate and methanol extracts exhibited the highest level of protection toward the direct mutagen, sodium azide, induced response. In addition to antimutagenic activity, these extracts showed an important free radical scavenging activity toward the 1, 1-diphenyl-2-picrylhydrazyl (DPPH) free radical with $\mathrm{IC}_{50}$ value of 15,14 and $20 \mathrm{~g} / \mathrm{ml}$, respectively[105]. The n-hexane fraction of an ethanol extract of Cyperus rotundus rhizomes was found to inhibit cell growth in ovarian cancer (A2780, SKOV3 and OVCAR3) and endometrial cancer (Hec1A and Ishikawa) cells. Among the thirteen sesquiterpenes isolated from the nhexane fraction, some patchoulane-type compounds, but not eudesmane-type compounds, showed moderate cytotoxic activity in human ovarian cancer cells. In particular, the patchoulane sesquiterpene 6-acetoxy cyperene had the most potent cytotoxicity. Propidium iodide/Annexin V staining and terminal deoxynucleotidyl transferase dUTP (deoxynucleotide triphosphate) nick end labeling assay were performed to study cell cycle progression and apoptosis. 6-acetoxy cyperene induced apoptosis, as shown by the accumulation of sub-G1 and apoptotic cells. Furthermore, treatment with 6-acetoxy cyperene stimulated the activation of caspase-3, caspase8 and caspase-9 and poly (ADP-ribose) polymerase in a dose-dependent manner. Pretreatment with caspase inhibitors neutralized the pro-apoptotic activity of 6-acetoxy cyperene[106]. To investigated the mode of anticancer effect of Cyperus rotundus, the pro-apoptotic effects of Cyperus rotundus rhizomes was studied in a human breast carcinoma MDA-MB-231 cell model. Treatment of MDA-MB-231 cells with an ethanol extract (EECR) and a methanol extract of Cyperus rotundus rhizomes (MECR), but not a water extract of Cyperus rotundus rhizomes, resulted in potent antiproliferative activity. The activity of the EECR was higher than that of the MECR and was associated with the induction of apoptosis. The induction of apoptosis by the EECR was associated with upregulation of death receptor 4 (DR4), DR5 and pro-apoptotic Bax, as well as down-regulation of anti-apoptotic survivin and Bcl-2. EECR treatment also down-regulated Bid expression and activated caspase- 8 and -9 , the respective initiator caspases of the extrinsic and intrinsic apoptotic pathways. The increase in mitochondrial membrane depolarization was correlated with activation of effector caspase-3 and cleavage of poly (ADP-ribose) polymerase, a vital substrate of activated caspase-3. Blockage of caspase activation by pretreatment with a pan-caspase inhibitor consistently inhibited apoptosis and abrogated growth inhibition in EECR-treated MDA-MB-231 cells. Although reactive oxygen species (ROS) increased following treatment with the EECR, inhibiting ROS with a ROS scavenger did not attenuate EECR-induced apoptosis. Furthermore, inhibitors of phosphatidylinositol 3-kinase (PI3K)/Akt and mitogen-activatedprotein kinase (MAPK) signaling pathways failed to reverse EECR-induced apoptosis and growth inhibition. These results revealed that the pro-apoptotic activity of the EECR may be regulated by a caspase-dependent cascade through activation of both intrinsic and extrinsic signaling pathways that was not associated with ROS generation or the PI3K/Akt and MAPK pathways[107].

\section{ANTIOXIDANT EFFECTS}


Antioxidant activity of Cyperus rotundus rhizomes extract (CRRE) was evaluated in a series of in vitro assay. CRRE exhibited scavenging effect in concentration dependent manner on superoxide anion radicals, hydroxyl radicals, nitric oxide radical, hydrogen peroxide, in addition to property of metal chelating and reducing power. The lipid peroxidation effect of the extract was also studied by thiobarbituric acid-reactive substances (TBARS) using young and aged rat brain mitochondria. The extract prevented mitochondrial lipid peroxidation induced by $\mathrm{FeSO}_{4}$ ascorbate in concentration dependent manner[108]. Cyperus rotundus extracted by different extraction solvents was evaluated for antioxidant activity using different in vitro antioxidant assays. Total flavonoids and polyphenols contents in methanol extracts of Cyperus rotundus were higher compared to ethanol extracts. Percent inhibition of linoleic acid system of methanol extracts of Cyperus rotundus (32.50$48.17 \%)$, DPPH free radical scavenging capacity (51.50-61.73\%) and reducing power (0.754-1.112) were higher as compared to ethanol extracts at concentration of $2.5-10.0 \mathrm{mg} / \mathrm{ml}[67]$.

\section{HYPOLIPIDEMIC AND WEIGHT CONTROL EFFECT}

Hypolipidaemic activity of Cyperus rotundus rhizomes was evaluated in high fat diet induced hyperlipidaemic rats $(70,140$ and $280 \mathrm{mg} / \mathrm{kg} \mathrm{bw})$. The results demonstrated statically significant reduction in serum lipid profile. Treatment with different doses of extract exerted statistically significant $(\mathrm{p}<0.05)$ reduction in serum total cholesterol, LDL, TG levels at the end of 15 days of intervention[63]. The preventive role of ethanolic extract of Cyperus rotundus rhizomes (CRRE) was investigated on ageassociated changes in glucose and lipids in young and aged rats. CRRE was given as $(500 \mathrm{mg} / \mathrm{kg}$ body weight) orally for 30 days. Age associated increase in serum glucose, total cholesterol, triglycerides, LDL cholesterol, VLDL cholesterol and a decrease in HDL cholesterol was observed in aged rats compared to young rats. Administration of CRRE to aged rats prevented the age associated changes in glucose, total cholesterol, triglycerides, LDL cholesterol and VLDL cholesterol. HDL cholesterol level was found to be increased significantly in both young and aged rats after treatment with CRRE[109]. The biological efficacy of Cyperus rotundus tubers extract was studied on weight control in obese Zucker rats. Administration of 45 or $220 \mathrm{mg} / \mathrm{kg} /$ day of Cyperus rotundus tubers hexane extract for 60 days in Zucker rats induced a significant reduction in weight gain without affecting food consumption or inducing toxicity. In vitro, $250 \mathrm{microg} / \mathrm{ml}$ of this extract was able to stimulate lipolysis in 3T3F442 adipocytes suggesting that this medicinal plant contained activators of beta-adrenoreceptors (AR). The binding assay performed on the rat beta3-AR isoform, known to induce thermogenesis, demonstrated that Cyperus rotundus tubers extract can consistently and effectively bind to this receptor. The data suggest that the effect on weight gain exerted by Cyperus rotundus tubers extract may be mediated, at least partially, through the activation of the beta3-AR[110].

\section{EFFECT ON PLATELET FUNCTION}

The antiplatelet activities of Cyperus rotundus ethanolic extract (CRE) and eight of its constituent compounds were evaluated by examining their effects on rat platelet aggregations in vitro and ex vivo, and on mice tail bleeding times. During the in vitro platelet aggregation study, CRE showed significant and concentration dependent inhibitory effects on collagen-, thrombin-, and/or arachidonic acid (AA)-induced platelet aggregation. Of its eight components, $(+)$-nootkatone was found to have the most potent inhibitory effect on collagen-, thrombin-, and AA-induced platelet aggregation. In addition, CRE- and (+)-nootkatonetreated mice exhibited significantly prolonged bleeding times. Furthermore, $(+)$-nootkatone had a significant inhibitory effect on rat platelet aggregation ex vivo[111].In studying the effect of Cyperus rotundus on the hemorrheological changes in normal rats, Cyperus rotundus can improve all hemorrheological indexes, such as the whole blood specific viscosity, the plasma specific viscosity, erythrocyte electrophoresis, etc[112].

\section{GASTROINTESTINAL EFFECT}

The antiulcer activity of crude extract of Cyperus rotundus was studied in rats at a dose of $(300 \mathrm{mg} / \mathrm{kg}$ and $500 \mathrm{mg} / \mathrm{kg}$ ). Ulcer was induced in rats by aspirin $300 \mathrm{mg} / \mathrm{kg}$. Crude extract induced significant antiulcer effect [81]. The protective effects of Cyperus rotundus on gastric mucosal damage induced by ischemia and reperfusion was studied in rats. Ischemia/reperfusion model was designed as $30 \mathrm{~min}$ ischemia followed by 60 min reperfusion by clamping the celiac artery. The Cyperus rotundus extracts were given at the doses of 100 or $200 \mathrm{mg} / \mathrm{kg}$ to prevent postischemic gastric mucosal injury. Antioxidant enzymes activity such as malondialdehyde and glutathione-peroxidase were measured in the gastric tissue. Histopathological sections were examined for ischemic injury. The mean ulcer index of rats treated with 200 and $100 \mathrm{mg} / \mathrm{kg}$ Cyperus rotundus were significantly lower $(\mathrm{p}<0.05)$ than that of control rats. The activities of antioxidant enzymes were significantly enhanced $(\mathrm{p}<0.05)$ by treatment with Cyperus rotundus extracts[113]. 
Decoctions of Cyperus rotundus rhizome were given orally $(1.25,2.5,4.0 \mathrm{~g}$ crude drug $/ \mathrm{kg}$ ) to rats $30 \mathrm{~min}$ before ethanol showed gastric ulcer inhibitory effect in a dose dependent manner[114]. The ulcer-preventive role of Cyperus rotundus was studied in rats treated with non-steroidal anti-inflammatory drugs. Oral administration of different doses of Cyperus rotundus rhizome methanolic extract $(250$ and $500 \mathrm{mg} / \mathrm{kg}$ ) significantly inhibited aspirin-induced gastric ulceration in animals in a dose-dependent manner $(49.32 \%$ and $53.15 \%$, respectively), which was also comparable with the standard gastric ulcer drug ranitidine. Administration of Cyperus rotundus rhizome methanolic extract also significantly increased the activity of superoxide dismutase, cellular glutathione and glutathione peroxidase, and inhibited the lipid peroxidation in the gastric mucosa of ulcerated animals in a dose-dependent manner[115].An aqueous extract of tubers of Cyperus rotundus (ACR) was tested for its antidiarrhoeal and antispasmodic activity. Antidiarrhoeal effect of ACR was evaluated in castor oil induced diarrhea in mice and antispasmodic effect was evaluated by charcoal meal test in mice at a dose of $125,250,500 \mathrm{mg} / \mathrm{kg}$. The \% inhibition of diarrhoea was $30.36 \%, 37.90 \%, 45.45$ $\%$ and $92.45 \%$ for ACR $125,250,500 \mathrm{mg} / \mathrm{kg}$ orally and loperamide $2 \mathrm{mg} / \mathrm{kg}$ dose orally respectively. ACR $125,250,500 \mathrm{mg} / \mathrm{kg}$ orally and atropine sulphate $2 \mathrm{mg} / \mathrm{kg}$ dose orally produced $24.35 \%, 31.48 \%, 36.75 \%$ and $55.94 \%$ inhibition of intestinal transit respectively[116]The methanol extract of Cyperus rotundus rhizome, given orally at the doses of 250 and $500 \mathrm{mg} / \mathrm{kg} \mathrm{bw}$, showed significant antidiarrhoeal activity in castor oil induced diarrhoea in mice. Among the fractions, tested at $250 \mathrm{mg} / \mathrm{kg}$, the petroleum ether fraction and residual methanol fraction showed antidiarrhoeal activity, the latter being more active as compared to the control. The ethyl acetate fraction did not show any antidiarrhoeal activity[117].The antidiarrheal activity of the decoction of Cyperus rotundus tubers was studied using representative assays of diarrheal pathogenesis. Antibacterial, antigiardial and antirotaviral activities were studied. Effect on adherence of enteropathogenic Escherichia coli (EPEC) and invasion of enteroinvasive E. coli (EIEC) and Shigella flexneri to HEp-2 cells was evaluated as a measure of effect on colonization. Effect on enterotoxins such as enterotoxigenic E. coli (ETEC) heat labile toxin (LT), heat stable toxin (ST) and cholera toxin (CT) was also assessed. The decoction showed antigiardial activity, reduced bacterial adherence to and invasion of HEp-2 cells and affected production of CT and action of LT. The decoction of Cyperus rotundus did not exerted marked antimicrobial activity and it is exerted its antidiarrheal action by mechanisms other than direct killing of the pathogen[118].The effect of Cyperus rotundus was investigated on adherence and enterotoxin production of 2 groups of E.coli enteropathogenic (EPEC) and enterotoxigenic (ETEC). A decoction of the root bulbs of Cyperus rotundus was prepared by boiling $1 \mathrm{gm}$ of plant material in $16 \mathrm{ml}$ distilled water till the volume was reduced to $4 \mathrm{ml}$. The decoction was then centrifuged at 2500 RPM for 10 minutes and filtered through a membrane of $0.22 \mu$ pore size before use. A significant inhibition in labile toxin production was noted at 24 hours, at a 1:2 dilution and at 72 hours at 1:2 and 1:100 dilution. Stable toxin was inhibited at 1:10, 1:100 and 1:1000 dilutions, maximum inhibition seen at 1:1000. An inverse correlation was observed between the stable toxin production and the concentration of the decoction[119].

\section{HEPATOPROTECTIVE EFFECT}

The effects of Cyperus rotundus rhizome on cellular lipogenesis and non-alcoholic/diet-induced fatty liver disease, and the molecular mechanism of these actions were studied. It appeared that the hexane fraction of Cyperus rotundus rhizome reduced the elevated transcription levels of sterol regulatory element binding protein-1c (SREBP-1c) in primary hepatocytes following exposure to the liver X receptor $\alpha$ (LXR $\alpha$ ) agonist. The SREBP-1c gene was a master regulator of lipogenesis and a key target of LXR $\alpha$. CRHF inhibited not only the LXR $\alpha$-dependent activation of the synthetic LXR response element (LXRE) promoter, but also the activation of the natural SREBP-1c promoter. Moreover, the hexane fraction of Cyperus rotundus decreased (i) the recruitment of RNA polymerase II to the LXRE of the SREBP-1c gene; (ii) the LXR $\alpha$-dependent upregulation of various lipogenic genes; and (iii) the $\operatorname{LXR} \alpha$-mediated accumulation of triglycerides in primary hepatocytes. Furthermore, the hexane fraction of Cyperus rotundus ameliorated fatty liver disease and reduced the expression levels of hepatic lipogenic genes in high sucrose diet (HSD)-fed mice. CRHF did not affect the expression of ATP-binding cassette transporter A1, another important LXR target gene that was required for reverse cholesterol transport (RCT) and protected against atherosclerosis. Accordingly, these results suggested that the hexane fraction of Cyperus rotundus might be a novel therapeutic remedy for fatty liver disease through the selective inhibition of the lipogenic pathway[120].

\section{ANTIDIABETIC EFFECT}

The antidiabetic effect of of Cyperus rotundus was evaluated on alloxan induced hyperglycemia in rats. Oral daily administration of $500 \mathrm{mg} / \mathrm{kg}$ of the extract once a day for seven consecutive days, significantly lowered the blood glucose levels[121]. Cyperus rotundus $(2.5 \mathrm{ml} / \mathrm{kg}$, orally of $10 \%$ of the aqueous decoction of tuber parts) significantly decreased fasting serum glucose level in alloxan induced diabetic and 
normoglycemic rabbits. Hypoglycemic effects was appeared from the first week of the treatment, and tended to be increased with the continuation of the treatment[122]. The preventive role of ethanolic extract of Cyperus rotundus rhizomes (CRRE) was investigated on age associated changes in glucose in young and aged rats. CRRE was given as $(500 \mathrm{mg} / \mathrm{kg}$ bw) orally for 30 days. Age associated increase in serum glucose was observed in aged rats compared to young rats. Administration of CRRE to aged rats prevented the age associated changes in glucose level[123].

\section{DERMATOLOGICAL EFFECT}

The alcoholic extract of tuber parts of Cyperus rotundus was examined for wound healing activity as ointment in three types of wound models in rats (the excision, the incision and dead space wound model). The ointments showed considerable difference in wound closure time and tensile strength in all wound models as compared to standard drug, nitrofurazone ointment $(0.2 \% \mathrm{w} / \mathrm{w})[123]$. The ethanol extract of Cyperus rotundus showed significant analgesic properties as evidenced by the significant reduction in the number of writhes and stretches induced in mice by $1.2 \%$ acetic acid solution. It also potentiated analgesia induced by morphine and pethidine in mice[82].Ethyl acetate and hexane fractions of the methanol extract of Cyperus rotundus were found to partially inhibit transient receptor potential vanilloid 1 channel activity, and at a concentration of $90 \mu \mathrm{M}$, oleanolic acid, which was one of three constituents isolated from the ethylacetate fraction, inhibited this activity by $61.4 \pm 8.0 \%$. The results highlight the potential therapeutic effects of Cyperus rotundus in the contexts of UV-induced photo-aging[102].The efficacy of topical Cyperus rotundus oil to decrease hair growth, was evaluated by an open-label pilot study. Eligible participants $(n=65)$ with unwanted axillary hair were assigned randomly to 3 study groups: topical Cyperus rotundus oil (group 1), saline (group 2), and Alexandrite laser (group 3). Three methods were used to evaluate the results: hair counts, observations of independent professionals, and patient self-assessments. Overall results did not differ significantly between Cyperus rotundus oil and the Alexandrite laser $(p>0.05)$. However, statistically significant differences were noted with respect to decrease of growth of white hair $(\mathrm{p}<0.05)$, favoring the oil. This finding was evident by all 3 methods (hair counts, observations of independent professionals, and patient self-assessments) of assessment. No side effects were detected[124].

\section{ANTI-DYSMENORRHEA EFFECT}

The anti-dysmenorrhea effect of the essential oil of the rhizome of Cyperus rotundus (EOC) was investigated in mice. Mice were divided into four groups: Group 1 served as control and group 2, group 3, group 4 were given low, middle and high dosage $(0.01 \mathrm{~g} / \mathrm{kg}, 0.02 \mathrm{~g} / \mathrm{kg}, 0.1 \mathrm{~g} / \mathrm{kg})$ of EOC respectively. The animals were first given diethylstilbestrol for 12 consecutive days $(2 \mathrm{mg} / \mathrm{kg} / \mathrm{day})$ by intragastric administration to create dysmenorrhea animal model. Different dosage of EOC and equivalent saline were given to animals in each group during the last three days. 30 mins after the last drug administration, the mice were injected intraperioneally with $0.1 \mathrm{ml}$ oxytocin injection and distortions were observed and recorded in 15 mins and 30 mins. EOC obtained from rhizome of Cyperus rotundus was subjected to column chromatography for fractionation, six fractions were obtained, namely F1-F6. EOC and its fractions F2 - F6 significantly reduced distortion times in 15 mins, 30mins after ip oxytocin injection; F4 performing the best among the fractions, it was contained spathulenol as well as $\beta$-caryophyllene oxide and isoaromadendrene oxide according to GC-MS analysis. Accordingly, EOC and its fractions F2 - F6 showed significant anti-dysmenorrhea. More than one components were attributed to anti-dysmenorrhea effect according to the GC-MS analysis of EOC and its fractions F2 - F6[125].

\section{EFFECT ON LYMPHOCYTES PROLIFERATION}

The proliferation of lymphocytes in the absence and presence of mitogens was assessed at a concentration range $1-1000 \mu \mathrm{g} / \mathrm{ml}$ of Cyperus rotundus extract. The tested extracts significantly enhanced the lymphocyte proliferation at $1 \mathrm{mg} / \mathrm{ml}[100]$.

\section{SIDE EFFECTS AND TOXICITY}

The $\mathrm{LD}_{50}$ of ethanol extract of the root, when administered intraperitoneally was $90 \mathrm{~g} / \mathrm{kg}$ in mice [126127]. Ethanol extract (defatted with petroleum ether) of dried roots administered ip to mice of both sexes showed $\mathrm{LD}_{50}>0.5 \mathrm{mg} / \mathrm{kg}[128]$. Ethanol-water $(1: 1)$ extract of rhizome administered ip to mice of both sexes produced $\mathrm{LD}_{50}$ of $681.0 \mathrm{mg} / \mathrm{kg}[129]$. The $\mathrm{LD}_{50}$ of the essential oils was $5000 \mathrm{mg} / \mathrm{kg}$ in rats[84]. The acute and subacute toxicities of the ethanol extract from Cyperus rotundus were evaluated in rats. A single oral 
administration of the ethanol extract at a dose of $5000 \mathrm{mg} / \mathrm{kg}$ did not produce signs of toxicity, behavioral changes, mortality and differences on gross appearance of internal organs. In subacute toxicity, all rats were received a repeated oral dose of $1000 \mathrm{mg} / \mathrm{kg}$ of the ethanol extract over 14 days. The satellite group was given the ethanol extract in the same period but kept for further 14 days without dosing in order to detect the delayed effects or reversibility of toxic effects. The results showed that the extract did not cause changes in terms of general behaviors, mortality, weight gain, hematological and clinical blood chemistry parameters. The results of gross and pathological examinations showed normal appearance of the internal organs as compared to those of the control group[130]. Toxicity and biochemical study of crude ethanolic extract of Cyperus rotundus was carried out in mice and rats. The extract was given at the dose of 10,100 and $1000 \mathrm{mg} / \mathrm{kg}$. None of the group exhibited any sign of toxicity at these doses. However, at the dose of $1000 \mathrm{mg} / \mathrm{kg}$, motor activity was slightly decreased. The effects of the extract of Cyperus rotundus were also investigated on different biochemical parameters (glucose, lipid profile, cardiac enzymes, liver enzymes and kidney function test). Liver enzymes were found normal, However, non significant increase in serum bilirubin, gamma-GT and SGPT was recorded. Hematological studies also showed non significant toxic changes. Histopathological examination also confirmed that the drug was safe and non toxic[131].

\section{CONCLUSION}

This review discuss the chemical constituent, pharmacological and therapeutic effects of Cyperus rotundus as promising herbal drug because of its safety and effectiveness.

\section{REFERENCES}

[1] Fransworth NR, Akerele O, Bingel AS, Soejarto DD and Guo Z. Medicinal plants in therapy. Bulletin of the World Health Organization 1985; 63 (6): 965-981.

[2] Fransworth NR, Akerele O, Bingel AS, Soejarto DD and Guo Z. Medicinal plants in therapy. Bulletin of the World Health Organization 1985; 63 (6): 965-981.

[3] Al-Snafi AE. The pharmacological importance of Aloe vera- A review. International Journal of Phytopharmacy Research 2015; 6(1) : 28-33.

[4] Al-Snafi AE. Chemical constituents and pharmacological effects of Citrullus colocynthis - A review. IOSR Journal of Pharmacy 2016; 6(3): 57-67.

[5] Al-Snafi AE. Medical importance of Cichorium intybus - A review IOSR Journal of Pharmacy 2016; 6(3): 41-56.

[6] Al-Snafi AE. Pharmacological importance of Clitoria ternatea - A review IOSR Journal of Pharmacy 2016; 6(3): 68-83.

[7] Al-Snafi AE. The medical Importance of Cicer arietinum - A review IOSR Journal of Pharmacy 2016; 6(3): 29-40.

[8] Al-Snafi AE. The pharmacological activities of Cuminum cyminum - A review. IOSR Journal of Pharmacy 2016; 6(6): 46-65.

[9] Al-Snafi AE. Medical importance of Cupressus sempervirens- A review. IOSR Journal of Pharmacy 2016; 6(6): 66-76.

[10] .Al-Snafi AE. The contents and pharmacology of Crotalaria juncea- A review. IOSR Journal of Pharmacy 2016; 6(6): 77-86.

[11] .Al-Snafi AE. The medical importance of Cydonia oblonga- A review. IOSR Journal of Pharmacy 2016; 6(6): 87-99.

[12] Al-Snafi AE. The pharmacology of Crocus sativus- A review. IOSR Journal of Pharmacy 2016; 6(6): 838.

[13] Al-Snafi AE. The chemical constituents and therapeutic importance of Cressa cretica- A review . IOSR Journal of Pharmacy 2016; 6(6): 39-46.

[14] Al-Snafi AE. The Pharmacological and therapeutic importance of Cordia myxa- A review. IOSR Journal of Pharmacy 2016; 6(6): 47-57.

[15] .Al-Snafi AE. The contents and pharmacological importance of Corchorus capsularis- A review. IOSR Journal of Pharmacy 2016; 6(6): 58-63.

[16] Al-Snafi AE. The chemical constituents and pharmacological effects of Convolvulus arvensis and Convolvulus scammonia- A review. IOSR Journal of Pharmacy 2016; 6(6): 64-75.

[17] Al-Snafi AE. Medicinal plants possessed anti-inflammatory antipyretic and analgesic activities (part 2)plant based review. Sch Acad J Pharm 2016; 5(5): 142-158.

[18] . Al-Snafi AE. Medicinal plants affected reproductive systems (part 2) - plant based review. Sch Acad J Pharm 2016; 5(5): 159-174. 
[19] .Al-Snafi AE. Medicinal plants with anticancer effects (part 2)- plant based review. Sch Acad J Pharm 2016; 5(5): 175-193.

[20] Al-Snafi AE. Antiparasitic, antiprotozoal, molluscicidal and insecticidal activity of medicinal plants (part 2) - plant based review. Sch Acad J Pharm 2016; 5(5): 194-207.

[21] Al-Snafi AE. Medical importance of Anthemis nobilis (Chamaemelum nobilis)- A review. Asian Journal of Pharmaceutical Science \& Technology 2016; 6(2): 89-95.

[22] Al-Snafi AE. Adonis aestivalis: pharmacological and toxicological activities- A revew. Asian Journal of Pharmaceutical Science \& Technology 2016; 6(2): 96-102.

[23] Al-Snafi AE. The Pharmaceutical importance of Althaea officinalis and Althaea rosea: A Review. Int J Pharm Tech Res 2013; 5(3):1387-1385.

[24] Al-Snafi AE. Pharmacological effects of Allium species grown in Iraq. An overview. International Journal of Pharmaceutical and health care Research 2013;1(4):132-147.

[25] Al-Snafi AE. Therapeutic properties of medicinal plants: a review of their detoxification capacity and protective effects (part 1). Asian Journal of Pharmaceutical Science \& Technology 2015; 5(4): 257-270.

[26] Al-Snafi AE. Therapeutic properties of medicinal plants: a review of plants with hypolipidemic, hemostatic, fibrinolytic and anticoagulant effects (part 1). Asian Journal of Pharmaceutical Science \& Technology 2015; 5(4): 271-284.

[27] Al-Snafi AE. Therapeutic properties of medicinal plants: a review of their effect on reproductive systems ( part 1). Ind J of Pharm Sci \& Res 2015; 5(4): 240-248.

[28] Al-Snafi AE. Therapeutic properties of medicinal plants: a review of their gastro-intestinal effects (part Ind J of Pharm Sci \& Res 2015; 5(4): 220-232.

[29] Al-Snafi AE. Therapeutic properties of medicinal plants: a review of their antiparasitic, antiprotozoal, molluscicidal and insecticidal activity (part 1). J of Pharmaceutical Biology 2015; 5(3): 203-217.

[30] Al-Snafi AE. Therapeutic properties of medicinal plants: a review of plants with antidiabetic effects (part J of Pharmaceutical Biology 2015; 5(3): 218-229.

[31] Al-Snafi AE. Therapeutic properties of medicinal plants: a review of plants with antifungal activity (part 1). Int J of Pharm Rev \& Res 2015; 5(3):321-327.

[32] Al-Snafi AE. Therapeutic properties of medicinal plants: a review of their dermatological effects (part 1). Int J of Pharm Rev \& Res 2015; 5(4):328-337.

[33] Al-Snafi AE. Therapeutic properties of medicinal plants: a review of plants with anticancer activity (part 1). Int J of Pharmacy 2015; 5(3): 104-124.

[34] Al-Snafi AE. Therapeutic properties of medicinal plants: a review of plants with anti-inflammatory, antipyretic and analgesic activity (part 1). Int J of Pharmacy 2015; 5(3): 125-147.

[35] Al-Snafi AE. Therapeutic properties of medicinal plants: a review of their immunological effects (part Asian Journal of Pharmaceutical Research 2015; 5(3): 208-216.

[36] Al-Snafi AE. Therapeutic properties of medicinal plants: a review of their antibacterial activity (part 1). International Journal of Pharmacology and Toxicology 2015; 6(3): 137-158.

[37] Al-Snafi AE. Therapeutic properties of medicinal plants: a review of plants with antioxidant activity (part 1). International Journal of Pharmacology and Toxicology 2015; 6(3): 159-182.

[38] Al-Snafi AE. Therapeutic properties of medicinal plants: a review of their respiratory effects ( part 1). International Journal of Pharmacological Screening Methods 2015; 5(2):64-71.

[39] Al-Snafi AE. Therapeutic properties of medicinal plants: a review of their antiviral activity (part 1). International Journal of Pharmacological Screening Methods 2015; 5(2): 72-79.

[40] Al-Snafi AE. Therapeutic properties of medicinal plants: a review of plants with cardiovascular effects (part 1). Int J of Pharmacology \& Toxicology 2015; 5(3): 163-176.

[41] Al-Snafi AE. Therapeutic properties of medicinal plants: a review of medicinal plants with central nervous effects (part 1). Int J of Pharmacology \& Toxicology 2015; 5(3): 177-192.

[42] Al-Snafi AE, Allahwerdi, IY. and Jawad IA. Using of topical 5\% urtica dioica ointment in treatment of psoriasis. European Journal of Biomedical and Pharmaceutical Sciences 2015; 2(4):103-111.

[43] Al-Snafi AE. Chemical constituents and pharmacological importance of Agropyron repens - A review. Research Journal of Pharmacology and Toxicology 2015; 1 (2): 37-41.

[44] Al-Snafi AE. Clinically tested medicinal plant: A review (Part 1). SMU Medical Journal 2016; 3(1): 99 128.

[45] Al-Snafi AE. Chemical constituents and pharmacological effects of Clerodendrum inerme-A review. SMU Medical Journal 2016; 3(1): 129-153.

[46] Global Invasive Species Database, Cyperus rotundus, http://www.issg. or/database/ species/ ecology.asp?si=1448 [27 April 2009] 
[47] United States Department of agriculture, Natural Resources Conservation Service. Cyperus rotundus L., nutgrass, http://plants.usda.gov/core/profile?symbol=CYRO

[48] USDA, ARS, National Genetic Resources Program. Germplasm Resources Information Network(GRIN). National Germplasm Resources Laboratory, Beltsville, Maryland. URL: http://www.arsgrin.gov.4/cgi-bin/npgs/html/taxon. pl?316644 (18 October 2015)

[49] Wills GD. Description of purple and yellow nutsedge (Cyperus rotundus and C. esculentus). Weed Technology 1987; 1: 2-9.

[50] FloraofNorthAmerica Cyperusrotundus,http://www.efloras.org/florataxon. aspx?flora_id=1\&taxon_id=200026713 [March, 2011]

[51] Hall DW, Vandiver VV and Ferrell JA. Purple Nutsedge, Cyperus rotundus L. Institute of Food and AgriculturalSciences,UniversityofFlorida2009, http://edis.ifas.ufl.edu/pdffiles/FW/FW01500.pdf

[52] Galinato MI, Moody K and Piggin CM. Upland rice weeds of south and southeast Asia. International Rice Research Institute, Makati City, Philippines 1999.

[53] Talukdar AD, Tarafdar RG, Choudhury MD, Nath D and Choudhury S. A review on pteridophyte antioxidants and their potential role in discovery of new drugs. Sci and Tech 2011; 7(1): 151-155.

[54] Yeung. Him-Che. Handbook of Chinese herbs and formulas. Institute of Chinese Medicine, Los Angeles 1985.

[55] Duke JA and Ayensu ES. Medicinal plants of China. Reference Publications, Inc. 1985.

[56] Bown D. Encyclopaedia of herbs and their uses. Dorling Kindersley, London. 1995.

[57] Chopra RN, Nayar SL and Chopra IC. Glossary of Indian medicinal plants. Council of Scientific and Industrial Research, New Delhi 1986.

[58] Sivapalan SR. Medicinal uses and pharmacological activities of Cyperus rotundus Linn - a review. International Journal of Scientific and Research Publications 2013; 3(5): 1-8.

[59] Sivapalan SR and Jeyadevan P. Physico-chemical and phyto-chemical study of rhizome of Cyperus rotundus Linn. International Journal of Pharmacology and Pharmaceutical Technology (IJPPT) 2012; 1(2): 42-46.

[60] Sharma SK and Singh AP. Morphological, microscopical and physico-chemical investigations on the rhizomes of Cyperus rotundus Linn. Research Journal of Pharmaceutical, Biological and Chemical Sciences 2011; 2(3): 798-806.

[61] Emelugo BN, Umerie SC, Okonkwo IF and Achufusi JN. Evaluation of the tubers and oil of Cyperus rotundus Linn ( Cyperaceae). Pakistan Journal of Nutrition 2011; 10(2): 147-150.

[62] Ghannadi A, Rabbani M, Ghaemmaghami L and Malekian N. Phytochemical screening and essential oil analysis of one of the Persian sedges; Cyperus rotuntdus L. IJPSR 2012; 3(2): 424-427.

[63] Chandratre RS, Chandarana S and Mengi SA. Lipid lowering activity of alcoholic extract of Cyperus rotundus. IJRPC 2011; 1(4): 1042- 1045.

[64] Huang KC. The dried tuber of Cyperus rotundus L. The pharmacology of Chinese herbs, $2^{\text {nd }}$ ed. 1999: 320-321.

[65] El-Gohary HMA. Study of essential oils of the tubers of Cyperus rotuntdus L and Cyperus alopecuroides ROTTB. Bull Fac Pharm Cairo Univ 2004; 42(1) :157-164.

[66] Bisht A, Bisht GRS, Singh M, Gupta R and Singh V. Chemical compsition and antimicrobial activity of essential oil of tubers of Cyperus rotundus Linn. collected from Dehradun (Uttarakhand). International Journal of Research in Pharmaceutical and Biomedical Sciences 2011; 2(2); 661-665.

[67] Bashir A, Sultana B, Akhtar FH, Munir A, Amjad M and ul Hassan Q. nvestigation on the antioxidant activity of Dheela grass (Cyperus rotundus). African Journal of Basic \& Applied Sciences 2012;4 (1): 1-

[68] Sharma SK and Singh AP. Antimicrobial investigations on rhizomes of Cyperus rotundus Linn. Der Pharmacia Lettre 2011; 3(3):427-431.

[69] Yu HH, Lee DH, Seo SJ and You YO. Anticariogenic properties of the extract of Cyperus rotundus. Am J Chin Med 2007; 35: 497-505.

[70] Kumar S, Kumar K, and Gautam SS. Antibacterial evaluation of Cyperus rotundus Linn. root extracts against respiratory tract pathogens. African Journal of Pharmacology and Therapeutics 2014; 3(3): 95-98.

[71] Muthu K, Hema M, Nagaraj S and Rengasamy R. In vitro antibacterial potential, phytochemical characterization of Cyperus rotundus flower extract. International Journal of Natural Products Research 2014; 4(1): 6-8.

[72] Nima ZA, Jabier MS, Wagi RI and Hussain HA. Extraction, identification and antibacterial activity of Cyperus oil from Iraqi Cyperus rotundus. Eng \& Technology 2010; 2(1): 1156-1163.

[73] Ahmad M, Mahayrookh, Mehjabeen, Bin Rehman A and Jahan N. Analgesic, antimicrobial and cytotoxic effect of Cyperus routunds ethanolic extract. Pakistan Journal of Pharmacology 2012;.29(2):713. 
[74] Soltan MM and Zaki AK. Antiviral screening of forty-two Egyptian medicinal plants. J Ethnopharmacol 2009;126(1):102-107.

[75] Xu HB, Ma YB, Huang XY, Geng CA, Wang H, Zhao Y, Yang TH, Chen XL, Yang CY, Zhang XM and Chen JJ. Bioactivity-guided isolation of anti-hepatitis B virus active sesquiterpenoids from the traditional Chinese medicine: rhizomes of Cyperus rotundus. J Ethnopharmacol 2015;171:131-140.

[76] Singh SP, Raghavendra K and Dash AP. Evaluation of hexane extract of tuber of root of Cyperus rotundus Linn (Cyperaceae) for repellency against mosquito vectors. J Parasitol Res 2009; 1: 1-5.

[77] Solita ES and Castor L. Phytochemical and pesticidal properties of barsanga (Cyperus rotundus Linn.). JPAIR Multidiscip J 2011; 6: 197-214.

[78] Vivek K, Bhat SK. Ovicidal and larvicidal activities of Cyperus giganteus Vahl and Cyperus rotundus Linn essential oils against Aedes albopictus (Skuse). Natural Product Radiance 2008; 7(5): 416-419.

[79] Thebtaranonth C, Thebtaranonth Y, Wanauppathamkul S and Yuthavong Y. Antimalarial sesquiterpenes from tubers of Cyperus rotundus: structure of 10,12-peroxycalamenene, a sesquiterpene endoperoxide. Phytochemistry 1995; 40:125-128.

[80] Singh N, Kulshrestha VK, Gupta MB and Bhargava KP. A pharmacological study of Cyperus rotundus. Indian J Med Res 1970; 58: 103-109.

[81] Ahmad M, Rookh M, Rehman AB, Muhammad N, Amber, Younus M and Wazir A. Assessment of antiinflammatory, anti-ulcer and neuro-pharmacological activities of Cyperus rotundus Linn. Pak J Pharm Sci 2014; 27(6-Special): 2241-2246.

[82] Pal D, Dutta S and Sarkar A. Evaluation of CNS activities of ethanol extract of roots and rhizomes of Cyperus rotundus in mice. Acta Pol Pharm 2009; 66(5): 535-541.

[83] Ha JH, Lee KY, Choi HC, Cho J, Kang BS, Lim JC and Lee DU. Modulation of radioligand binding to the $\mathrm{GABA}_{\mathrm{A}}$-benzodiazepine receptor complex by a new component from Cyperus rotundus. Biol Pharm Bull 2002; 25(1): 128-130.

[84] Biradar S, Kangralkar VA, Mandavkar YM, Thakur M and Chougule. Anti-inflammatory, antiarthritic, analgesic and anticonvulsant activity of Cyperus essential oils. Int J Pharm Pharm Sci 2010; 294 (4): 112115.

[85] Khalili M, Kiasalari Z, Roghani M and Azizi Y. Anticonvulsant and antioxidant effect of hydroalcoholic extract of Cyperus rotundus rhizome on pentylentetrazole-induced kindling model in male mice. Journal of Medicinal Plants Research 2011; 5(7):1140-1146.

[86] Mayur P, Pawan P, Ashwin S and Pravesh S. Evaluation of anticovulsant activity of roots and rhizomes of Cyperus rotundus Linn in mice. International Research Journal of Pharmacy 2011; 2 (10): 37-41.

[87] Rabbani M, Ghannadi A and Malekian N. Evaluation of the effect of Cyperus rotundus L. in scopolamine-induced learning deficit in mice. Adv Biomed Res 2014; 3: 217.

[88] Lee CH, Hwang DS, Kim HG, Oh H, Park H, Cho JH, Lee JM, Jang JB, Lee KS and Oh MS. Protective effect of Cyperi rhizoma against 6-hydroxydopamine-induced neuronal damage. J Med Food 2010; 13(3): 564-571.

[89] Dabaghian FH, Hashemi M, Entezari M, Movassaghi S, Goushegir SA, Kalantari S, Movafagh A and Sharifi ZN. Effect of Cyperus rotundus on ischemia-induced brain damage and memory dysfunction in rats. Iran J Basic Med Sci 2015; 18(2): 199-204.

[90] Sunil AG, Kesavanarayanan KS, Kalaivani P, Sathiya S, Ranju V, Priya RJ, Pramila B, Paul FD, Venkhatesh $\mathrm{J}$ and Babu CS. Total oligomeric flavonoids of Cyperus rotundus ameliorates neurological deficits, excitotoxicity and behavioral alterations induced by cerebral ischemic-reperfusion injury in rats. Brain Res Bull 2011; 84(6): 394-405.

[91] Jebasingh D, Devavaram Jackson D, Venkataraman S, Adeghate E and Starling Emerald B. The protective effects of Cyperus rotundus on behavior and cognitive function in a rat model of hypoxia injury. Pharm Biol 2014; 52(12): 1558-1569.

[92] Hemanth Kumar K, Tamatam A and Pal A, Khanum F. Neuroprotective effects of Cyperus rotundus on SIN-1 induced nitric oxide generation and protein nitration: ameliorative effect against apoptosis mediated neuronal cell damage. Neurotoxicology 2013; 34: 150-159.

[93] Sundaram MS, Sivakumar T and Balamurugan G. Anti-inflammatory effect of Cyperus rotundus Linn. leaves on acute and subacute inflammation in experimental rat models. Biomedicine 2008; 28: 302-304.

[94] Soumaya KJ, Dhekra M, Fadwa C, Zied G, Ilef L, Kamel G and Leila CG. Pharmacological, antioxidant, genotoxic studies and modulation of rat splenocyte functions by Cyperus rotundus extracts. BMC Complement Altern Med 2013; 13: 28.

[95] Imam MZ and Sumi CD. Evaluation of antinociceptive activity of hydromethanol extract of Cyperus rotundus in mice. BMC Complement Altern Med 2014; 14: 83.

[96] Nam JH and Lee DU. Inhibitory effect of oleanolic acid from the rhizomes of Cyperus rotundus on transient receptor potential vanilloid 1 channel. Planta Med 2015; 81(1): 20-25. 
[97] Gupta MB, Palit TK, Singh N and Bhargava KP. Pharmacological studies to isolate the active constituents from Cyperus rotundus possessing anti-inflammatory, anti-pyretic and analgesic activities. Indian Journal of Medical Research 1971; 59: 76-82.

[98] Birdar S, Kangralkar V A, Mandavkar Y, Thakur M and Chougule N, Anti-inflammatory, anti-arthritic, analgesic anticonvulsant activity of cyperus essential oils. Int J Pharm Parmaceut Sci 2010; 2(4): 112115.

[99] Dang GK, Parekar RR, Kamat SK, Scindia AM and Rege NN. Antiinflammatory activity of Phyllanthus emblica, Plumbago zeylanica and Cyperus rotundus in acute models of inflammation. Phytother Res 2011; 25(6):904-908.

[100] Saxena RC, Punhami, Palit TK, Garg KC, Singh N and Kohli RP. Preliminary report on the antiinflammatory activity of Cyperus rotundus in cojunctivities (in human subjects). Indian J Pharm 1971; 3:.

[101] Singh N, Singh SP, Dixit KS, Saxena RC and Kohli RP. A placebo controlled clinical trial of Cyperus rotundus, Withania somnifera and their combination in cases of rheumatoid arthritis. Proc International Seminar on Clinical Pharmacology in Developing Countries, Lucknow, India 1986; 2:18-21.

[102] Seo WG, Pae HO, Oh GS, Chai KY, Kwon TO, Yun YG, Kim NY and Chung HT. Inhibitory effects of methanol extract of Cyperus rotundus rhizomes on nitric oxide and superoxide productions by murine macrophage cell line, RAW 264.7 cells. J Ethnopharmacol 2001; 76(1): 59-64.

[103] Jung SH, Kim SJ, Jun BG, Lee KT, Hong SP, Oh MS, Jang DS and Choi JH. $\alpha$-Cyperone, isolated from the rhizomes of Cyperus rotundus, inhibits LPS-induced COX-2 expression and PGE2 production through the negative regulation of NFאB signaling in RAW 264.7 cells. J Ethnopharmacol 2013; 147(1): 208-214.

[104] Tsoyi K1, Jang HJ, Lee YS, Kim YM, Kim HJ, Seo HG, Lee JH, Kwak JH, Lee DU and Chang KC. (+)-Nootkatone and (+)-valencene from rhizomes of Cyperus rotundus increase survival rates in septic mice due to heme oxygenase-1 induction. J Ethnopharmacol 2011; 137(3): 1311-1317.

[105] Kilani S, Ben Ammara R, Bouhle I, Abdelwahed A, Hayder N, Mahmoud A, Ghedira K and ChekirGhedira L. Investigation of extracts from (Tunisian) Cyperus rotundus as antimutagens and radical scavengers. Environmental Toxicology and Pharmacology 2005; 20: 478484.

[106] Ahn JH, Lee TW, Kim KH, Byun H, Ryu B, Lee KT, Jang DS and Choi JH. 6-acetoxy cyperene, a patchoulane-type sesquiterpene isolated from Cyperus rotundus rhizomes induces caspase-dependent apoptosis in human ovarian cancer cells. Phytother Res 2015,10. doi: 10.1002/ptr.5385.

[107] Park SE, Shin WT, Park C, Hong SH, Kim GY, Kim SO, Ryu CH, Hong SH and Choi YH. Induction of apoptosis in MDA-MB-231 human breast carcinoma cells with an ethanol extract of Cyperus rotundus L. by activating caspases. Oncol Rep 2014; 32(6): 2461-2470.

[108] Nagulendran KR, Velavan S and Mahesh R. In vitro antioxidant activity and total polyphenolic content of Cyperus rotundus rhizomes. E- Journal of Chemistry 2007; 4(3): 440-449.

[109] Nagulendran KR, Mahesh R and Begum VH, Preventive role of Cyperus rotundus rhizomes extract on age associated changes in glucose and lipids, Pharmacologyonline 2007; 2: 318-325.

[110] Lemaure B, Touché A, Zbinden I, Moulin J, Courtois D, Macé K and Darimont C. Administration of Cyperus rotundus tubers extract prevents weight gain in obese Zucker rats. Phytother Res 2007; 21: 724730.

[111] Seo EJ, Lee DU, Kwak JH, Lee SM, Kim YS and Jung YS. Antiplatelet effects of Cyperus rotundus and its component (+)-nootkatone. Journal of Ethnopharmacology 2011; 135: 48-54.

[112] Xue JX, Jiang Y and Yan YQ. Effects of the combination of Astragalus membranaceus (Fisch.) Bge. (AM), tail of Angelica sinensis (Oliv.) Diels. (TAS), Cyperus rotundus L. (CR), Ligusticum chuanxiong Hort. (LC) and Paeonia veitchii Lynch (PV) on the hemorrheological changes in normal rats. Zhongguo Zhong Yao Za Zhi 1993; 18(10): 621-623.

[113] Guldur ME, Ozgonul A, Kilic IH, Sogut O, Ozaslan M, Bitiren M, Yalcin M and Musa D. Gastroprotective effect of Cyperus rotundus extract against gastric mucosal injury induced by ischemic and reperfusion in rats. Int J Pharmacology 2010; 6(2): 104-110.

[114] Zhu M, Luk HH, Fung HS and Luk CT. Cytoprotective effects of Cyperus rotundus against ethanol induced gastric ulceration in rats. Phytother Res 1997; 11(5): 392-394.

[115] Thomas D, Govindhan S, Baiju EC, Padmavathi G, Kunnumakkara AB and Padikkala J. Cyperus rotundus L. prevents non-steroidal anti-inflammatory drug-induced gastric mucosal damage by inhibiting oxidative stress. J Basic Clin Physiol Pharmacol 2015; 26(5): 485-490.

[116] Shamkuwar PB, Hoshamani AH and Indrajeet D. Antispasmodic effect of Cyperus rotundus L (Cyperaceae) in diarrhoea. Der Pharm Lettre 2012; 4: 522-224.

[117] Uddin SJ, Mondal K, Shilpi JA and Rahman MT. Antidiarrhoeal activity of Cyperus rotundus. Fitoterapia 2006; 77(2): 134-136. 
[118] Daswani PG, Brijesh S, Tetali P and Birdi TJ. Studies on the activity of Cyperus rotundus Linn. tubers against infectious diarrhea. Indian J Pharmacol 2011; 43: 340-344.

[119] Daswani PG, Birdi TJ and Antia NH. Study of action of Cyperus rotundus root decoction on the adherence and enterotoxin production of diarrhoeagenic Escherichia coli. Indian Journal of Pharmacology 2001; 33: 116-117.

[120] Oh GS, Yoon J, Lee GG, Kwak JH and Kim SW. The Hexane fraction of Cyperus rotundus prevents non-alcoholic fatty liver disease through the inhibition of liver $\mathrm{X}$ receptor $\alpha$-mediated activation of sterol regulatory element binding protein-1c. Am J Chin Med. 2015; 43(3): 477-494.

[121] Raut NA and Gaikwad NJ. Antidiabetic activity of hydro-ethanolic extract of Cyperus rotundus in alloxan induced diabetes in rats. Fitoterapia 2006; 77: 585-588.

[122] Al-Snafi AE, Al-Trikrity AH. and Ahmad RH. Hypoglycemic effect of Teucrium polium and Cyperus rotundus in normal and diabetic rabbits. Med J Tikrit Univ 2013; 9(2): 1-10.

[123] Puratchikody A, Devi NC and Nagalakshmi G. Wound healing activity of Cyperus rotundus Linn. Indian Journal of Pharmaceutical Sciences 2006; 68: 97-101.

[124] Mohammed A and Ghada F. Topical Cyperus rotundus oil: a new therapeutic modality with comparable efficacy to Alexandrite laser photo-epilation. Aesthet Surg J 2014; 34(2): 298-305.

[125] Chen Y, Wang J, Liu L and Huang L. Anti-dysmenorrhea components from the rhizomes of Cyperus rotundus Linn. (Cyperaceae). $8^{\text {th }}$ OAPS Working Paper Series Paper No. 2011-027, http://www.oaps.hk/

[126] Akperbekova BA and Abdullaev RA. Diuretic effect of drug from and galenicals from the roots of Cyperus rotundus growing in Azerbaidzhan. Izv Akad Nauk Azerb SSR, Ser Biol Nauk 1966; 4: 98105.

[127] Akperbekova BA, and Guseinov DY. Studies on the influence of pharmaceutic preparations from rhizomes of Cyperus rotundus growing in Azerbaidzhen on the heart and vascular system. Azerb Med Zeh 1966; 43(7): 12-17.

[128] Woo WS, Lee EB and Chang I. Biological evaluation of Korean medicinal plants II. Yakhak Hoe Chi $1977 ; 21: 177-183$.

[129] 129.Dhawan BN, Dubey MP, Mehrotra BN, Rastogi RP, and Tandon JS. Screening of Indian plants for biological activity. Part 9. Indian Journal of Experimental Biology 1980; 18: 594-606.

[130] Thanabhorn S, Jaijoy K, Thamaree S, Ingkaninan K and Panthong A. Acute and subacute toxicities of the ethanol extract from the rhizomes of Cyperus rotundus Linn. Mahidol University Journal of Pharmaceutical Sciences 2005; 32(1-2): 15-22.

[131] Ahmad M, Mehjabeen M, Rehman AB and Noor Jahnan. Toxicological and biochemical evaluation of ethanolic crude extract of Cyperus rotundus. Int J Pharm Pharm Sci 2013; 5(4): 538-554. 